\title{
GAMBARAN MENGUNYAH MENTIMUN TERHADAP KEBERSIHAN GIGI DAN MULUT
}

\author{
Tritania Ambarwati ${ }^{1}$ \\ ${ }^{1}$ Dental Therapy, Poltekkes Kemenkes Tasikmalaya, Jawa Barat, Indonesia \\ *drgtritania@gmail.com
}

\begin{tabular}{l}
\hline Informasi artikel \\
\hline Sejarah artikel: \\
Diterima \\
Revisi \\
Dipublikasikan \\
\hline
\end{tabular}

Kata kunci:

Mengunyah mentimun, kebersihan gigi dan mulut

Key word:

Chewing cucumbers, dental and oral hygiene

\begin{abstract}
ABSTRAK
Tujuan dari penelitian ini adalah mengetahui bagaimana gambaran mengunyah mentimun terhadap kebersihan gigi dan mulut di Asrama Putra Jurusan Keperawatan Gigi Poltekkes Kemenkes Tasikmalaya. Metode penelitian menggunakan metode deskriptif. Populasi dalam penelitian ini adalah semua mahasiswa laki-laki yang bertempat tinggal di asrama Jurusan Keperawatan Gigi tahun 2015 yang berjumlah 33 orang, karena sampel kurang dari 100 maka digunakan total sampling. Alat ukur untuk kebersihan gigi dan mulut digunakan Debris Indeks dan mengunyah mentimun menggunakan lembar ceklis, analisis data menggunakan distribusi frekuensi. Berdasarkan hasil pengloahan dan analisis data diperoleh kesimpulan perubahan nilai rata-rata debris index pada mahasiswa laki-laki di asrama sebelum mengunyah mentimun $=1,65$ dengan kriteria sedang dan ratarata sesudah mengunyah mentimun $=0,49$ dengan kriteria baik. Data tersebut menunjukkan adanya selisih rata-rata sebelum dan sesudah mengunyah mentimun $=1,16$ yang berarti nilai debris index cenderung menurun.
\end{abstract}




\section{PENDAHULUAN}

Dalam tubuh yang sehat, terdapat jiwa yang kuat, demikian kata bijak yang menyiratkan pemaknaan bahwa kesehatan jasmani manusia merupakan kunci guna mendapatkan jiwa yang sentosa. Kesehatan juga dapat dianggap sebagai kebutuhan vital manusia yang dapat disejajarkan dengan kebutuhan akan sandang, pangan dan papan (Subarja, 2012). Kesehatan merupakan faktor terpenting dalam kehidupan manusia. Berkembangnya berbagai macam penyakit sekarang ini menyebabkan kehidupan yang sehat menjadi hal yang langka dan mahal, oleh karena itu diharapkan kesehatan di masyarakat dapat terwujud secara optimal (Krisna, 2010). Mengunyah adalah menghancurkan atau melumatkan makanan di dalam mulut dengan menggunakan gigi (Kemdikbud, 2014). Sariningsih (2012) juga menjelaskan bahwa dalam proses mengunyah, gigi geligi, rahang, bibir, kelenjar ludah dan otot sekitar rongga mulut harus berfungsi dengan baik. Lebih lanjut menurut Sulaksono, dkk., (2013) mengunyah makanan yang baik dan benar serta tidak terburu-buru akan membantu mulut untuk menghasilkan air liur, selain baik bagi kesehatan gigi, juga akan membantu lambung. Mengunyah makanan sedikitnya 32 kali, merangsang pengeluaran saliva lebih banyak sehingga dapat memberikan efek pembersihan gigi geligi sendiri (Cahyati, 2013).

Kesehatan di masyarakat dapat terwujud secara optimal, salah satu caranya adalah dengan meningkatkan pemeliharaan dibidang kesehatan gigi dan mulut. Kesehatan gigi dan mulut sangat penting bagi kesehatan tubuh secara umum dan sangat mempengaruhi kualitas kehidupan, termasuk fungsi bicara, pengunyahan dan rasa percaya diri. Gangguan kesehatan mulut akan berdampak pada kinerja seseorang (Putri, dkk., 2010). Kesehatan gigi juga penting untuk diperhatikan karena mulut merupakan pintu gerbang pertama di dalam proses pencernaan. Makanan dan minuman akan diproses di dalam mulut dengan bantuan gigi, lidah, dan saliva. Pemeliharaan kebersihan gigi dan mulut yang utama adalah dengan menyikat gigi, di samping itu, bisa juga dilakukan pemeliharaan tambahan lainnya yang mendukung untuk membersihkan gigi secara alami yaitu salah satunya dengan memakan buah dan sayuran yang renyah (Margareta, 2012).

Buah dan sayuran renyah dapat mengangkat noda secara maksimal tanpa merusak enamel gigi dan bekerja seperti sikat gigi alami dan pemutih gigi (Margareta, 2012). Cairan yang dikeluarkan oleh buah dan sayur tersebut mengandung larutan asam yang cukup sehingga tidak membuat gigi berlubang. Larutan asam tersebut dapat membantu menghilangkan sebagian noda pada gigi. Berikut merupakan sebagian contoh buah dan sayuran renyah yang baik untuk gigi yaitu apel, bengkuang, jambu biji, wortel dan mentimun (Erwana, 2013).

Cahyono (2003) menyatakan bahwa mentimun bukan tanaman asli Indonesia, tetapi berasal dari daerah beriklim sedang (sub tropis). Mentimun adalah salah satu sayuran buah yang banyak dikonsumsi segar oleh masyarakat (Sumpena, 2002). Menurut Calvin (2012) mentimun terkenal dengan kandungan airnya yang berlimpah, dan itu membuatnya sangat berguna untuk mempertahankan kebersihan mulut. Menurut Sahid (2010), kandungan kimia yang terdapat pada biji mentimun adalah minyak lemak dan karoten. Kandungan kimia yang terdapat pada daun mentimun adalah stigmasterol dan kukurbitasin $\mathrm{C}$ yang merupakan senyawa yang mempunyai aktifitas sebagai anti tumor. Kandungan kimia yang terdapat pada buah dari mentimun juga mengandung sedikit saponin yang bermanfaat sebagai anti kanker, enzim pencernaan, glutathione, protein, lemak, karbohidrat, vitamin B dan vitamin C. Kalium yang terdapat pada mentimun juga merupakan komponen utama dalam plasma darah juga mempengaruhi kerja otot jantung (Irianto dan Waluyo, 2004). Mentimun juga memiliki efek membersihkan gigi dengan membantu membuang deposit yang berkontribusi pada terbentuknya asam penyebab terjadinya gigi berlubang yaitu plak. 
Plak gigi menurut Putri, dkk., (2010) adalah deposit lunak yang melekat erat pada permukaan gigi, terdiri atas mikroorganisme yang berkembang biak dalam suatu matrik interseluler jika seseorang melalaikan kebersihan gigi dan mulutnya. Lebih lanjut menurut Sariningsih (2012) plak ini juga berpengaruh terhadap kesehatan jaringan pendukung gigi seperti gusi dan tulang pendukungnya, dengan demikian, dari plak bisa menimbulkan

Hasil survey Riset Kesehatan Dasar (Riskesdas) tahun 2013, menunjukkan bahwa prevalensi penduduk yang bermasalah pada gigi dan mulut di Indonesia sekitar 25,9\%. Persentase penduduk Indonesia yang tidak menggosok gigi sekitar 6,2\% sedangkan dari 93,8\% penduduk Indonesia yang menyikat gigi, hanya 2,3\% yang menyikat gigi dengan benar. Berdasarkan karakteristik jenis kelamin, laki-laki hanya 2,0\% yang menyikat gigi dengan benar, laki-laki lebih rendah dibandingkan dengan perempuan dalam memelihara kesehatan gigi dan mulut (Kemenkes, 2013).

Berdasarkan hasil pra penelitian yang dilakukan pada tanggal 14 April 2015 pada 7 dari 10 orang mahasiswa laki-laki Jurusan Keperawatan Gigi Poltekkes Kemenkes Tasikmalaya, diketahui tingkat kebersihan gigi dan mulut rata-rata memiliki kriteria sedang, untuk mengatasi permasalahan tersebut maka dilakukan cara lain utuk membantu membersihkan gigi secara maksimal. Alternatif tambahan untuk membersihkan gigi disamping dengan menggosok gigi salah satunya adalah dengan makan buah dan sayur yang renyah. Mentimun dalam kehidupan sehari-hari yang biasanya digunakan sebagai pelengkap bahan makanan berupa lalapan dan bahan acar, bisa juga digunakan untuk pencuci mulut setelah makan berat. Nilai lebih mentimun sebagai pencuci mulut adalah sebagai pembersih gigi alami karena mengandung serat dan air. Mentimun selain mudah ditemukan, juga bisa didapat dengan harga yang relatif murah sehingga bisa dikonsumsi oleh semua kalangan (Wijaya, 2014). Melalui latar belakang masalah tersebut maka tujuan dari penelitian ini adalah mengetahui bagaimana gambaran mengunyah mentimun terhadap kebersihan gigi dan mulut di Asrama Putra Jurusan Keperawatan Gigi Poltekkes Kemenkes Tasikmalaya tahun 2015

\section{METODE}

Jenis penelitian yang dilakukan adalah penelitian observasional dengan rancangan penelitian menggunakan metode deskriptif. Metode deskriptif yaitu penelitian yang bertujuan untuk menjelaskan atau mendeskripsikan suatu keadaan, atau peristiwa, untuk mengetahui gambaran mengunyah mentimun terhadap kebersihan gigi dan mulut di Asrama Putra Jurusan Keperawatan Gigi Poltekkes Kemenkes Tasikmalaya (Setyosari, 2010). Populasi dalam penelitian ini adalah semua mahasiswa laki-laki yang bertempat tinggal di asrama Jurusan Keperawatan Gigi tahun 2015 yang berjumlah 33 orang. Sampel dalam penelitian ini diperoleh dengan cara total sampling yaitu semua mahasiswa laki-laki yang bertempat tinggal di asrama Jurusan Keperawatan Gigi tahun 2015 sebanyak 33 orang (Notoatmodjo, 2005). Alat ukur untuk kebersihan gigi dan mulut digunakan Debris Indeks dan mengunyah mentimun menggunakan lembar ceklis. Penelitian ini data diolah dan dianalisa dengan menggunakan distribusi frekuensi sebelum dan sesudah pemberian mentimun.

\section{HASIL DAN PEMBAHASAN}

Hasil penelitian ini difokuskan kepada debris index sebelum dan sesudah mengunyah mentimun. Distribusi frekuensi sampel penelitian berdasarkan kriteria debris index sebelum diberi perlakuan mengunyah mentimun dapat dilihat pada tabel berikut: 
Tabel 1. Distribusi Frekuensi Sampel Penelitian Berdasarkan Kriteria Debris Index Sebelum Mengunyah Mentimun

\begin{tabular}{cccc}
\hline No. & Kriteria Debris Index & Jumlah & Persentase $(\%)$ \\
\hline 1. & Baik & 0 orang & $0 \%$ \\
\hline 2. & Sedang & 26 orang & $78,8 \%$ \\
\hline 3. & Buruk & 7 orang & $21,2 \%$ \\
\hline & Jumlah & 33 orang & 100 \\
\hline
\end{tabular}

Tabel 1 menunjukkan bahwa berdasarkan kriteria debris index pada mahasiswa lakilaki yang tinggal di asrama sebelum diberi perlakuan mengunyah mentimun mayoritas memiliki kriteria sedang yaitu sebanyak 26 orang $(78,8 \%)$. Kemudian hasil pemeriksaan distribusi frekuensi sampel penelitian berdasarkan kriteria debris index sesudah diberi perlakuan mengunyah mentimun dapat dilihat pada tabel berikut:

Tabel 2. Distribusi Frekuensi Sampel Penelitian Berdasarkan Kriteria Debris Index Sesudah Mengunyah Mentimun

\begin{tabular}{cccc} 
No. & Kriteria Debris Index & Jumlah & Persentase (\%) \\
\hline 1. & Baik & 28 orang & $84,8 \%$ \\
\hline 2. & Sedang & 5 orang & $15,2 \%$ \\
\hline 3. & Buruk & 0 orang & $0 \%$ \\
\hline & Jumlah & 33 orang & 100 \\
\hline
\end{tabular}

Tabel 2 menunjukkan bahwa berdasarkan kriteria debris index pada mahasiswa lakilaki yang tinggal di asrama sesudah diberi perlakuan mengunyah mentimun mayoritas memiliki kriteria baik yaitu sebanyak 28 orang $(84,8 \%)$. Hasil pemeriksaan distribusi frekuensi sampel penelitian berdasarkan kriteria debris index rata-rata sebelum dan sesudah diberi perlakuan mengunyah mentimun dapat dilihat pada tabel berikut:

Tabel 3. Distribusi Frekuensi Sampel Penelitian Berdasarkan Nilai Rata-Rata Debris Index Sebelun dan Sesudah Mengunyah Mentimun

\begin{tabular}{lccc}
\hline No. & Kriteria debris index & Jumlah nilai DI sebelum & Jumlah nilai DI sesudah \\
\hline 1. & Baik & 0 & 11,83 \\
\hline 2. & Sedang & 39,66 & 4,32 \\
\hline 3. & Buruk & 14,67 & 0 \\
\hline & Jumlah & 54,33 & 16,15 \\
\hline & Rata-rata & 1,65 & 0,49 \\
\hline
\end{tabular}

Rata-rata sebelum mengunyah mentimun didapat nilai debris index sebesar 1,65 yang merupakan kriteria sedang dan rata-rata sesudah mengunyah mentimun didapat nilai debris index sebesar 0,49 yang merupakan kriteria baik. Data tersebut menunjukkan adanya selisih rata-rata sebelum dan sesudah mengunyah mentimun sebesar 1,16 yang berarti nilai debris index menurun. Mentimun mempunyai kadar serat dan kandungan air yang berlimpah, sebagaimana menurut Cahyati (2013) yang menyatakan bahwa memakan makanan yang berserat perlu dikunyah lebih lama sehingga dari gerakan mengunyah dapat merangsang pengeluaran saliva lebih banyak. Saliva mengandung zat-zat seperti substansi 
antibakteri, senyawa glikoprotein, kalsium, dan fluorida yang sangat berguna melindungi gigi. Lebih lanjut menurut Calvin (2012) bahwa kandungan air yang ada di dalam mentimun akan menstimulasi kelenjar saliva untuk terus memproduksi saliva sehingga membuatnya cukup berperan dalam menjaga kebersihan gigi dan mulut.

Mengkonsumsi buah dan sayur dengan kadar air dan serat yang mencukupi akan membantu orang yang memiliki kadar saliva yang sangat pekat dan sedikit sehingga akan lebih mudah untuk terjadinya lubang pada gigi dibanding dengan karakteristik orang yang memiliki kadar saliva lebih banyak. Pada dasarnya seseorang yang memiliki kadar saliva pekat dan sedikit maka sisa makanan akan lebih mudah menempel pada permukaan gigi. Mengunyah makanan berserat dan berair seperti pepaya, apel, jambu biji, bengkuang merupakan sebagian contoh dari makanan yang dapat membantu membersihkan gigi secara alami (Siripipatthanakul, 2011, Cit., Cahyati, 2013).

Penelitian tentang makanan yang berserat dan berair dalam membersihkan plak gigi diantaranya buah bengkuang yang telah dilakukan oleh Octaya tahun 2010. Terdapat perbedaan pada buah bengkuang dengan mentimun, yaitu dalam buah bengkuang kandungan serat lebih banyak dari pada air sedangkan pada mentimun kandungan air yang lebih banyak dari pada serat. Perbedaan tersebut tidak membuat keefektivan buah bengkuang dan mentimun dalam membersihkan gigi berkurang, karena fakta buah dan sayur yang mengandung serat dan air dalam membersihkan plak sudah terbukti dengan penelitian-penelitian yang sudah dilakukkan. Berdasarkan dari hasil tersebut, diharapkan mentimun yang merupakan salah satu jenis sayuran yang sering dikonsumsi masyarakat sebagai lalapan bisa juga disisihkan untuk digunakan setelah makan besar karena mempunyai fungsi untuk membersihkan gigi secara alami.

\section{KESIMPULAN}

Berdasarkan hasil pengloahan dan analisis data diperoleh kesimpulan perubahan nilai rata-rata debris index pada mahasiswa laki-laki di asrama sebelum mengunyah mentimun = 1,65 dengan kriteria sedang dan rata-rata sesudah mengunyah mentimun $=0,49$ dengan kriteria baik. Data tersebut menunjukkan adanya selisih rata-rata sebelum dan sesudah mengunyah mentimun $=1,16$ yang berarti nilai debris index cenderung menurun dan hasil penelitian ini memberikan pengaruh. Kandungan dari mentimun yang berperan dalam membantu membersihkan gigi dari plak dan menurunkan nilai debris index adalah kadar serat dan kandungan airnya yang berlimpah

\section{DAFTAR PUSTAKA}

Be Kien Nio. 1987. Preventive Dentistry untuk Sekolah Pengatur Rawat Gigi bagian 1. Bandung: YKGI.

Cahyati, W. H. 2013. Konsumsi Pepaya (Carica Papaya) dalam Menurunkan Debris Index. Jurnal Kesehatan Masyarakat. Semarang. Diakses melalui: http://download.portalgaruda.org/article.php?article=136168\&val=5652 pada tanggal 24 Februari 2015.

Cahyono, B. 2003. Timun. Semarang: Aneka Ilmu.

Calvin, J. 2012. Mentimun Membantu Mempertahankan Kesehatan Gigi Anda. Diakses melalui: http://www.formulaoralcare.com/mentimun-membantu-mempertahankankesehatan-gigi-anda/ pada tanggal 11 Januari 2015. 
Erwana, A. F. 2013. Seputar Kesehatan Gigi dan Mulut. Yogyakarta: Rapha Publishing.

Fianti, S. 2011. Khasiat Timun Suri. Artikel. Diakses melalui: https://atikofianti.wordpress.com/category/khasiat-buah/page/2/ pada tanggal 25 Februari 2015.

Gerbode, S. J. 2012. Mekanisme Ulir Sulur Tanaman Mentimun. Artikel. Diakses melalui: http://www.kesimpulan.com/2012/09/mekanisme-ulir-sulur-tanamanmentimun.html?m=1 pada tanggal 25 Februari 2015.

Ghofur, A. 2012. Buku Pintar Kesehatan Gigi dan Mulut. Yogyakarta: Mitra Buku.

Irianto, K. dan Waluyo, K. 2004. Gizi dan Pola Hidup Sehat. Bandung: Yrama Widya.

Kemdikbud. 2014. KBBI. Diakses melalui: http://kbbi.web.id/ pada tanggal 25 Januari 2015 .

Kemenkes. 2013. Rencana Strategis Kementerian Kesehatan. Diakses melalui: http://www.litbang.depkes.go.id/sites/download/rkd2013/Laporan_Riskesdas2013.P DF pada tanggal 15 Januari 2015.

Krisna, T. 2010. 101 Ramuan Tradisional. Yogyakarta: Insania.

Margareta, S. 2012. 101 Tips dan Terapi Alami agar Gigi Putih dan Sehat. Yogyakarta: Pustaka Cerdas.

Octaya, R. 2010. Pengaruh Buah Bengkuang Dalam Membantu Membersihkan Plak Gigi Pada Mahasiswa Laki-Laki Jurusan Kesehatan Gigi Politeknik Kesehatan Tasikmalaya Tahun 2010. Karya Tulis Ilmiah JKG Poltekkes Tasikmalaya. Tasikmalaya.

Pramulita, S. 2014. Pengaruh Air Kelapa Muda terhadap Kebersihan Gigi dan Mulut Pada Mahasiswa Tingkat II Jurusan Keperawatan Gigi Tasikmalaya Tahun 2014. Karya Tulis Ilmiah JKG Poltekkes Tasikmalaya. Tasikmalaya.

Putri, M. H., Herijulianti, E dan Nurjannah, N. 2010. Ilmu Pencegahan Penyakit Jaringan Keras dan Jaringan Pendukung Gigi. Jakarta: EGC.

Ridwana, V. 2012. Kandungan Gizi dan Manfaat Buah Mentimun. Artikel. Diakses melalui:http://ridwanaz.com/kesehatan/kandungan-gizi-dan-manfaat-buahmentimun/ pada tanggal 25 Februari 2015.

Rumariati, R. 2013. Perbandingan Mengkonsumsi Buah Semangka dengan Buah Melon terhadap Kebersihan Gigi dan Mulut dengan Menggunakan Debris Indeks Pada Mahasiswa Tingkat 1A Jurusan Keperawatan Gigi Politeknik Kesehatan Tasikmalaya Tahun 2013. Karya Tulis Ilmiah JKG Poltekkes Tasikmalaya. Tasikmalaya.

Sahid, D. M. 2010. Mengobati Penyakit dengan Aneka Sayuran. Bandung: Atikan Mandiri. 
Saputri, C. Y. 2013. Pertumbuhan dan Perkembangan Tanaman Timun. Artikel. Diakses melalui: http://galeridaun.blogspot.com/2013/10/pertumbuhan-tanaman-cabe-terongdan.html pada tanggal 25 Februari 2015.

Sariningsih, E. 2012. Merawat Gigi Anak Sejak Usia Dini. Jakarta: Elex Media Komputindo.

Setyosari, P. 2010. Metode penelitian pendidikan dan pengembangan. Jakarta: Kencana.

Soebroto, I. 2009. Apa yang Tidak Dikatakan Dokter Tentang Kesehatan Gigi Anda. Yogyakarta: Bookmarks.

Subarja, L. M. 2012. Buku Pintar Panduan Terlengkap Hidup Sehat. Yogyakarta: Aulya Publishing.

Sulaksono, S., Daryanto, E., dan Prihastuti, W. 2013. Aturan Makan yang Baik Menurut Rasulullah SAW. Diakses melalui: http://www.tipscaraterbaik.com/aturan-makanyang-baik-menurut-rasulullah-saw.html pada tanggal 27 Januari 2015.

Sumpena, U. 2002. Budi Daya Mentimun Intensif, dengan Mulsa, secara Tumpang Gilir. Jakarta: Penebar Swadaya.

Sunaryono, H. 2003. Kunci Becocok Tanam Sayur-Sayuran Penting di Indonesia (Produksi Hortikultura II). Bandung: Sinar Baru Algensindo.

Wijaya, S. 2014. Tangkal Diabetes dan Tumpas Racun dalam Tubuh dengan Khasiat Mentimun. Yogyakarta: Flash Books.

Yahaya, M. S. 2014. Faedah Makan Timun Apa Khasiatnya. Artikel. Diakses melalui: http://www.gerbangtelukbahang.com/ pada tanggal 25 Februari 2015.

Yusuf, S. 2014. Psikologi Perkembangan Anak dan Remaja. Bandung: Remaja Rosdakarya 